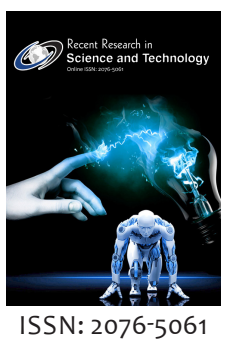

Received: December 7, 2019 Accepted: December 25, 2019 Published: December 31, 2019

*Corresponding Author: M. Cüneyt Bağdatli Email: cuneytbagdatli@ gmail.com

\section{Evaluation with trend analysis of the open surface evaporation in observed for many years: The case study in Nevsehir province of Turkey}

\author{
M. Cüneyt Bağdatli'* Yigitcan Balli \\ ${ }^{1}$ Nevsehir Haci Bektas Veli University, Engineering and Architecture Faculty, Department of Biosystem Engineering, \\ Nevsehir, Turkey, ${ }^{2}$ Nevsehir Haci Bektas Veli University, Institute of Science, Department of Environmental \\ Engineering, Nevsehir, Turkey
}

\begin{abstract}
In this study, the trends of the climate station belonging to the Turkish General Directorate of Meteorology in the center of Nevsehir province of Turkey between 2001-2019 years were subjected to the Rho's correlation tests of Mann Kendall and Sperman for years of maximum open surface evaporation and total open surface evaporation. According to the results of the trend analysis, the maximum open surface evaporation was $59,7 \mathrm{~mm}$ and the total open surface evaporation was calculated as 1013,2 mm in the center of Nevsehir Province over long period. It was observed that the average maximum temperature value was $24^{\circ} \mathrm{C}$ for long years and the total precipitation average was $363,6 \mathrm{~mm}$. It was observed that there was a significant increase in open surface evaporation values varying in years in spring, winter and autumn. According to the trend analysis results made for many years, a trend was not observed in the Maximum and total open surface evaporation parameters in Nevsehir province of Turkey.
\end{abstract}

KEYWORDS: Open surface evaporation, global climate change, trend analysis, Nevsehir province, Turkey

\section{INTRODUCTION}

Global climate change, which has shown its effect in recent years, manifests itself in negative dimensions in all areas. It is under the threat of World Climate change with the increase of carbon emission and greenhouse gas effect. Carbon is one of the basic elements of life. However, increasing $\mathrm{CO}_{2}$ amount in the atmosphere depending on human needs and consumption decreases the protective effect of the bard layer and causes irregularities in temperature and precipitation. Continuing carbon emissions at this rate until 2050 will prepare an environment for the average temperature to rise up to $1,5-4,5^{\circ} \mathrm{C}$ in the world [1].

Studies show that the temperature will increase $0,1{ }^{\circ} \mathrm{C}$ every ten years [2]. Especially the increase in fossil fuel consumption constitutes $56 \%$ of greenhouse gas emissions, while the destruction of forest areas causes 17\% increase in greenhouse gas increase. However, in recent studies, it has been revealed that the amount of $\mathrm{CO}_{2}$ has reached the highest level in the last 80 years, reaching 402,9 ppm per million.

While the average of precipitation for many years in our country was $631 \mathrm{~mm}$, this amount has decreased by 7\% in 2000 and this rate has increased gradually due to global warming. In parallel with the increasing tendency of the temperature, these decreases observed in precipitation will cause larger problems related to waterresources [3]. In this study, it was carried out to analyze the long-term total and maximum monthly precipitation values, the maximum, minimum and average temperature values observed in the center of Nevsehir Province between 2001-2019, by trend analysis and to reveal the increase or decrease tendencies.

\section{MATERIAL AND METHOD}

The study area is located in Turkey's Central Anatolian province of Nevsehir Center. In the study, the long-term monthly total and maximum open surface evaporation values of the climate observation station of the Nevşehir Provincial Directorate of Meteorology between 2001-2019 were used as materials in the study. The location and location of Nevsehir Province, which is the subject of the study, can be seen on the map given in Figure 1.

In the study, monthly changes of the open surface evaporation values observed between the meteorology station in the center of Nevsehir province between 2001-2019 [4]. It was analyzed for 228 months in total and the values obtained were statistically

\footnotetext{
Copyright: $\odot$ The authors. This article is open access and licensed under the terms of the Creative Commons Attribution License (http://creativecommons.org/licenses/by/4.0/) which permits unrestricted, use, distribution and reproduction in any medium, or format for any purpose, even commercially provided the work is properly cited. Attribution — You must give appropriate credit, provide a link to the license, and indicate if changes were made.
} 


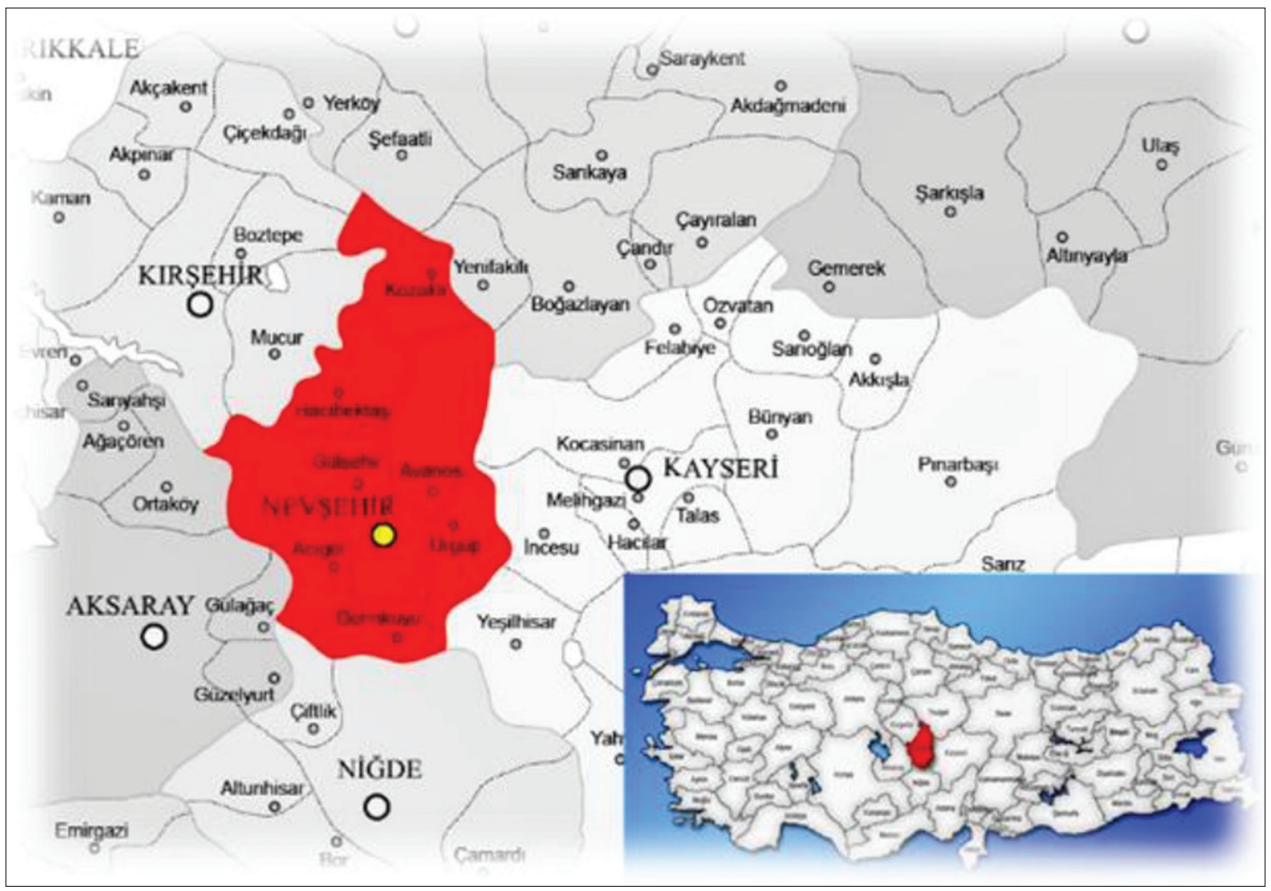

Figure 1: Location and location of the research area

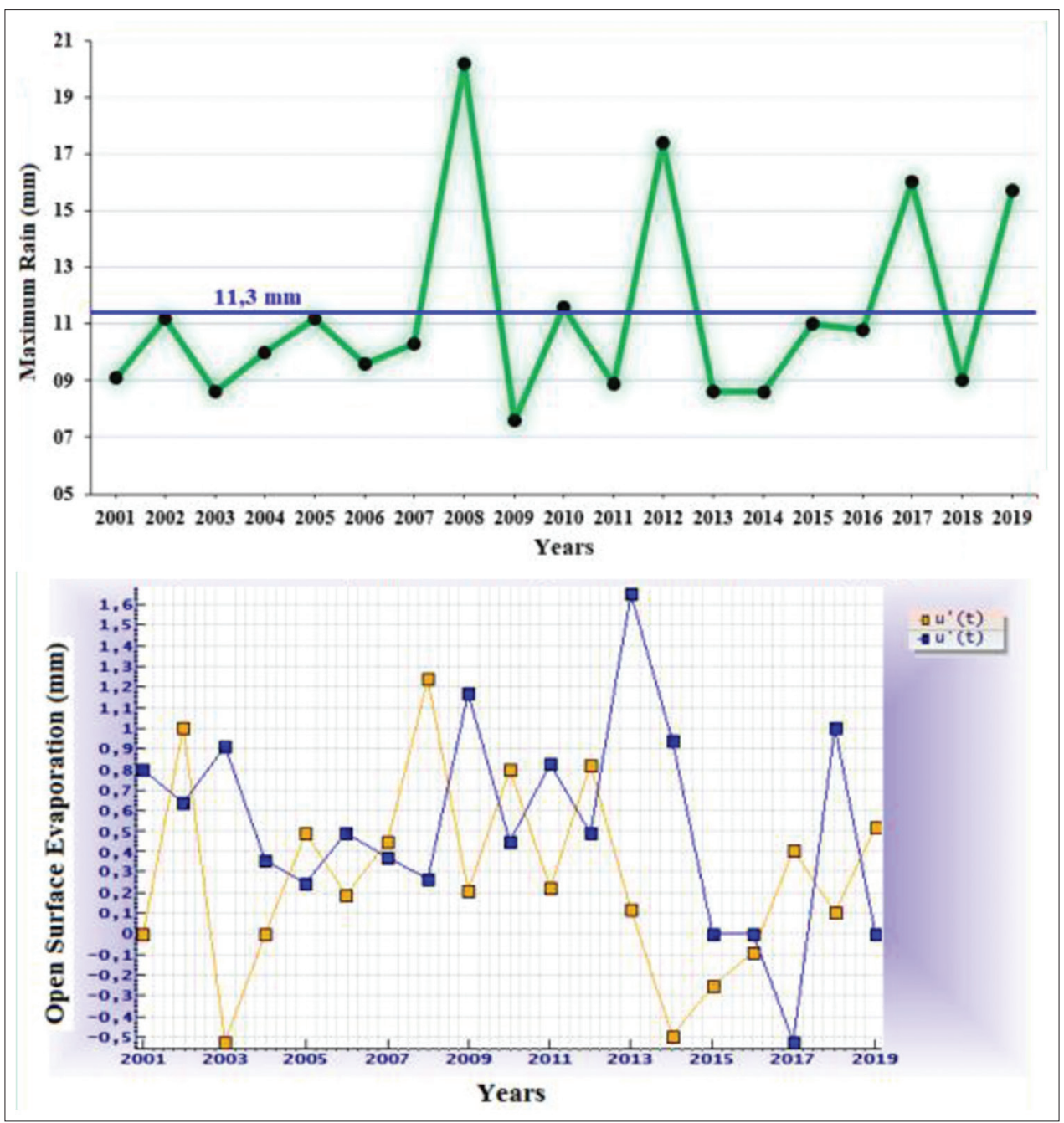

Figure 2: Maximum open surface evaporation in total spring months $(\mathrm{mm})$ over long periods 
based on graphs and charts. In the study, total and maximum open surface evaporation changes have been subjected to trend analysis for many years. In this sense, in order to evaluate the data, it was evaluated within the scope of Rho, Kendall Test of Mann Kendall and Sperman and Trend method of Sen and it was performed in the $95 \%$ confidence level $[5,6]$. In the study, a software called “Trend Analysis for Windows”, Mann-Kendall test, Spearman's Rho test, Mann-Kendall Order Correlation test and Sen's Trend Slope method are applied to the data and the result is given as graphics and text [7].

\section{FINDINGS}

Trend analysis results of maximum open surface evaporation and total open surface evaporation values for many years between 2001-2019 belonging to Center of The Nevşehir Province are presented in detail below.

\section{Maximum Open Surface Evaporation Observed Over a Long Period}

Maximum open surface evaporation values in Center of The Nevsehir Province which were analyzed for many years (2001-2019), were evaluated seasonally (spring, autumn, summer) with trend analysis. The trend of changing the average maximum open surface evaporation values for long years in spring is also shown in detail in the graph given in Figure 2.

According to the results of the analysis, long year spring months were the year in which the maximum open surface evaporation values were the lowest, and this year 7,2 mm open surface evaporation change was recorded. In 2008, an open surface evaporation value of $20,2 \mathrm{~mm}$, the highest value of maximum open surface evaporation, was recorded. The maximum annual open evaporation average for the long spring months is $11,2 \mathrm{~mm}$. Since long term average maximum open surface evaporation values in winter are close to zero, winter months values have not been analyzed by years. The distribution of long-term average maximum open surface evaporation changes in summer months by years is given in Figure 3 .

Considering the maximum open surface evaporation values in the summer months for many years, the lowest observed maximum open surface evaporation value was recorded as $27,7 \mathrm{~mm}$ in 2009 , while the highest measured maximum open surface evaporation value was recorded as $37,3 \mathrm{~mm}$ in 2002 .

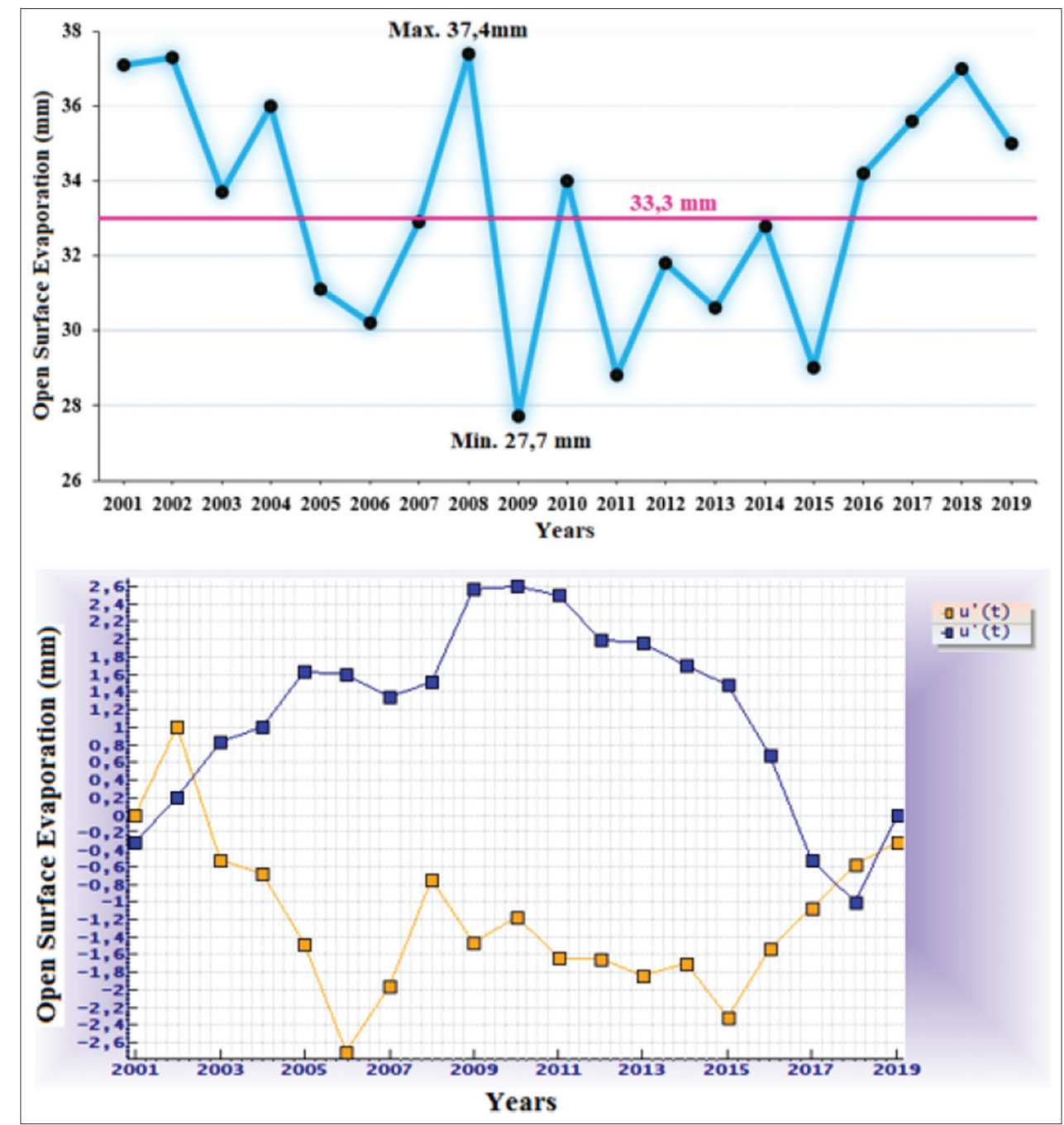

Figure 3: The average of the maximum open surface evaporation $(\mathrm{mm})$ in total summer months $(\mathrm{mm})$ over long periods 


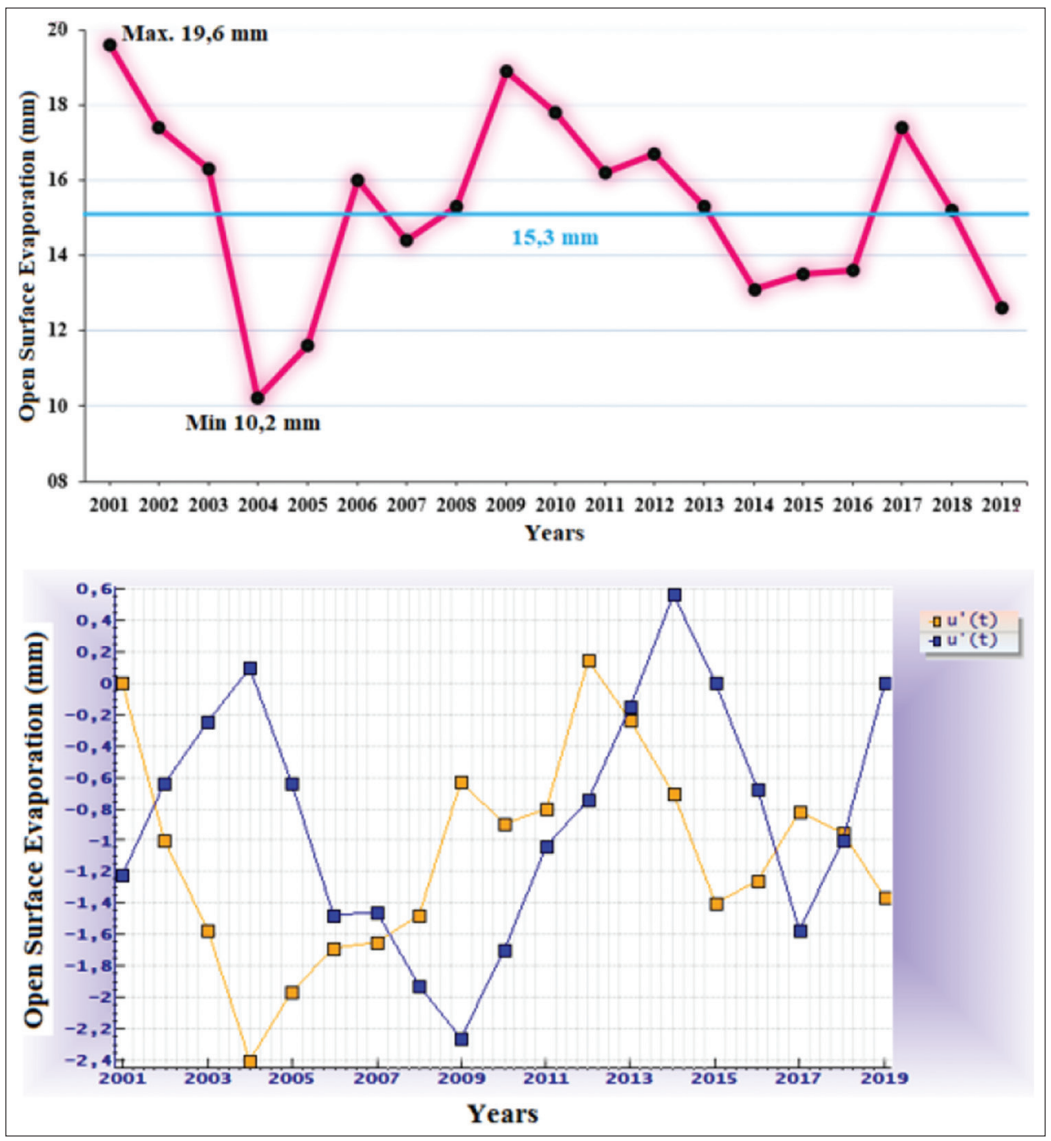

Figure 4: The average of the maximum open surface evaporation $(\mathrm{mm})$ in total autumn months $(\mathrm{mm})$ over long periods

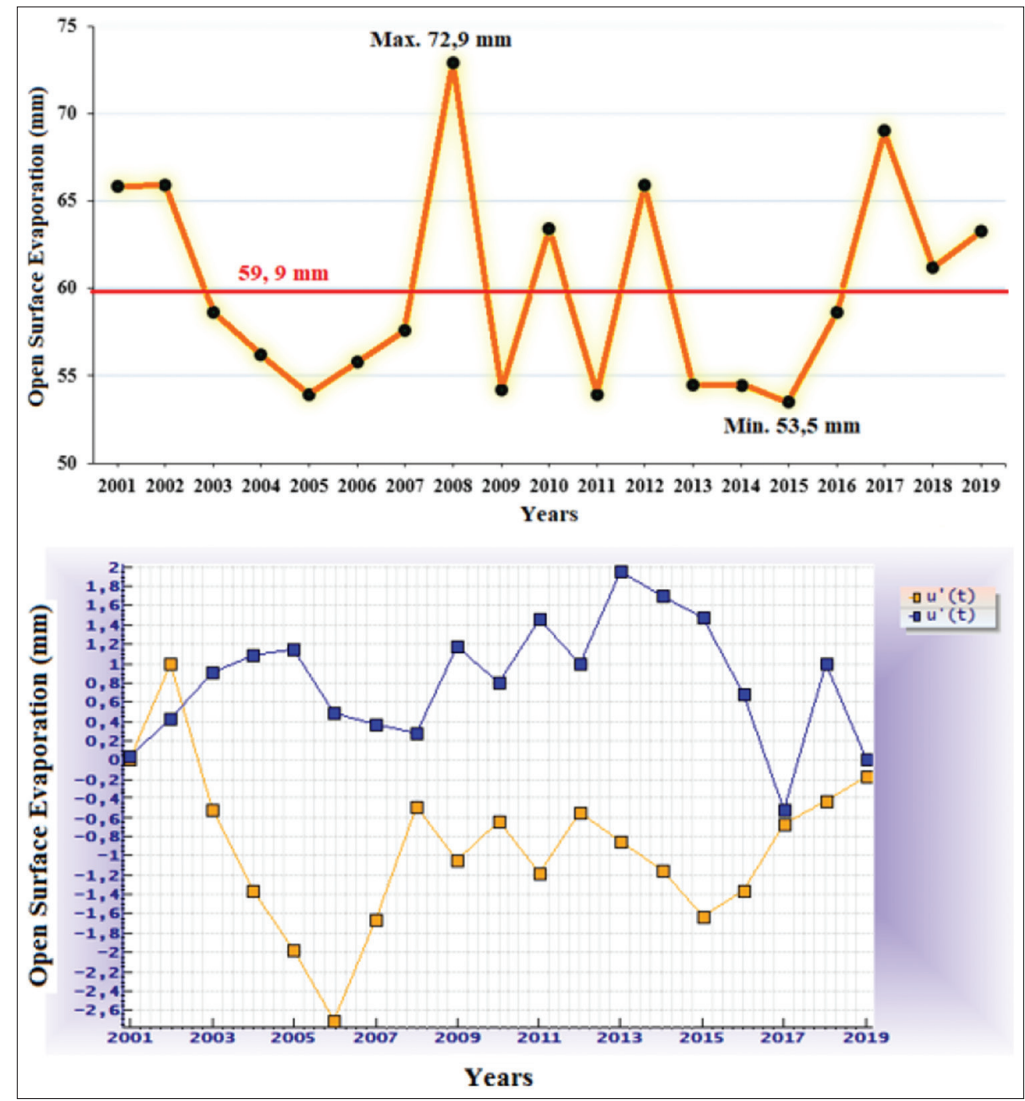

Figure 4a: The average of maximum open surface evaporation $(\mathrm{mm})$ in all months $(\mathrm{mm})$ over long periods 
The average maximum open surface evaporation in the summer months was recorded as $33 \mathrm{~mm}$. The distributions of the average maximum open surface evaporation values observed in the autumn months for many years are presented in detail on the graph given in Figure 4 and $4 a$.

When looking at the distribution of maximum open surface evaporation in autumn months for many years, the lowest maximum open surface evaporation was the year 2004 and 10,2 mm open surface evaporation was recorded. The highest was $19,6 \mathrm{~mm}$ in 2001. The average maximum open surface evaporation value for long years autumn months was recorded as $15,5 \mathrm{~mm}$. The distribution of maximum open surface evaporation values, which are observed as the average of all seasons for many years, is presented in Figure 5.

Considering the maximum open surface evaporation average values for many years, the lowest was $53,5 \mathrm{~mm}$ in 2015 , the highest was 72,9 $\mathrm{mm}$ in 2008 and the maximum open surface evaporation average was $59,7 \mathrm{~mm}$ for many years. Trend analysis results in maximum open surface evaporation changes for long years are given in Table 1.
According to the trend analysis results regarding maximum open surface evaporation for many years, it is concluded that there is no trend on the basis of spring, autumn, summer and general totals and that the open surface evaporation values progress in the average course according to Rho Tests of Mann-Kendall and Sperman.

\section{Total Open Surface Evaporation Observed Over a Long Period}

Total open surface evaporation values in Nevşehir city center, which were analyzed for many years (2001-2019), were evaluated seasonally (spring, autumn, summer) with trend analysis. The

Table 1: The trend analysis results of average maximum open surface evaporation for many years

\begin{tabular}{|cccc|}
\hline Parameters & Seasons & $\begin{array}{c}\text { Mann-Kendall } \\
\text { Test Statistics }\end{array}$ & $\begin{array}{c}\text { Spearman's Rho } \\
\text { Test Statistics }\end{array}$ \\
\hline $\begin{array}{c}\text { Max. Open } \\
\text { Surface } \\
\text { Evaporation } \\
(2001-2019)\end{array}$ & Spring & No Trend & No Trend \\
\cline { 2 - 4 } & Autumn & No Trend & No Trend \\
\hline & Summer & No Trend & No Trend \\
\hline
\end{tabular}

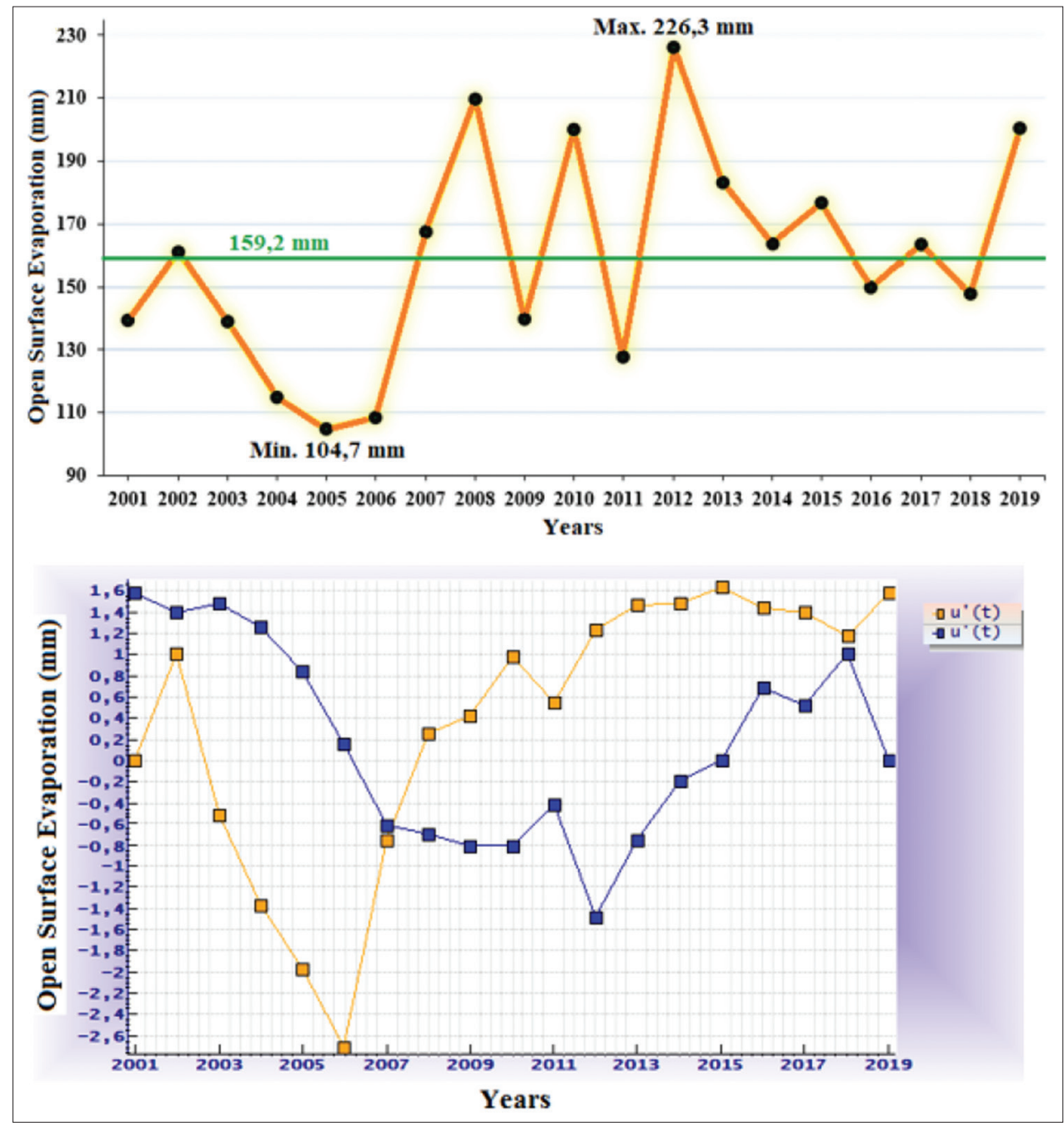

Figure 5: The average of the total open surface evaporation $(\mathrm{mm})$ in spring months $(\mathrm{mm})$ over long periods 


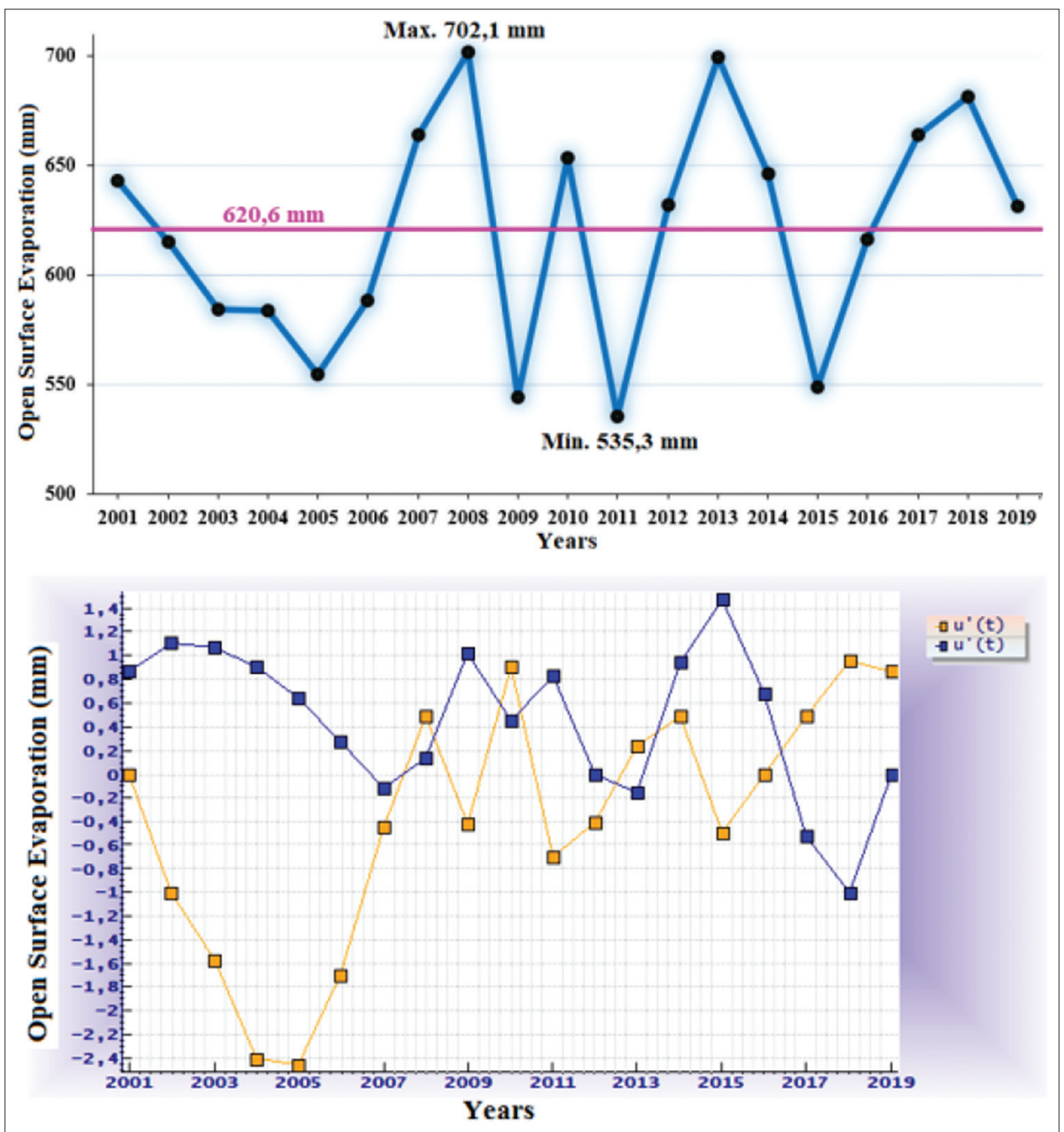

Figure 6: The average of the total open surface evaporation $(\mathrm{mm})$ in summer months $(\mathrm{mm})$ over long periods

course of the change in the total open surface evaporation values for the spring months for many years is also shown in detail in the graph given in Figure 5.

According to the results obtained, long year spring months was the year in which the total open surface evaporation values remained the lowest, whereas $104,7 \mathrm{~mm}$ open surface evaporation change was recorded in this year, while in 2012, the highest value of total open surface evaporation was $226,3 \mathrm{~mm}$. open surface evaporation value was recorded. Long-term spring months total open surface evaporation averages were determined to be $157,5 \mathrm{~mm}$. Since long term average maximum open surface evaporation values in winter are close to zero, winter months values have not been analyzed by years. Distribution of longterm average total open surface evaporation changes in summer months by years is given in Figure 6 .

Considering the total open surface evaporation values in the summer months for many years, the lowest observed total open surface evaporation value was recorded as $544,5 \mathrm{~mm}$ in 2009, while the highest measured total open surface evaporation value was recorded as $702,1 \mathrm{~mm}$ in 2008 . The
Table 2: The trend analysis results of average total open surface evaporation for many years

\begin{tabular}{cccc}
\hline Paremeter & Seasons & $\begin{array}{c}\text { Mann-Kendall Test } \\
\text { Statistics }\end{array}$ & $\begin{array}{c}\text { Spearman's Rho } \\
\text { Test Statistics }\end{array}$ \\
\hline $\begin{array}{c}\text { Total Open } \\
\text { Surface } \\
\text { Evaporation } \\
(2001-2019)\end{array}$ & Spring & No Trend & No Trend \\
\cline { 2 - 5 } & Autumn & No Trend & No Trend \\
\cline { 2 - 5 } & Summer & No Trend & No Trend \\
\hline
\end{tabular}

average total open surface evaporation in the summer months was recorded as $616,3 \mathrm{~mm}$. The distribution of the average total open surface evaporation values observed in the autumn months for many years are presented in detail on the graph given in Figure 7.

When looking at the distribution of total open surface evaporation in the autumn months for many years, the lowest total open surface evaporation was observed in 2004 and 161,7 $\mathrm{mm}$ open surface evaporation was recorded. The highest was $307,6 \mathrm{~mm}$ in 2017. The average total open surface evaporation value for many years and autumn months was recorded as $243.6 \mathrm{~mm}$. The distribution of the total open surface 


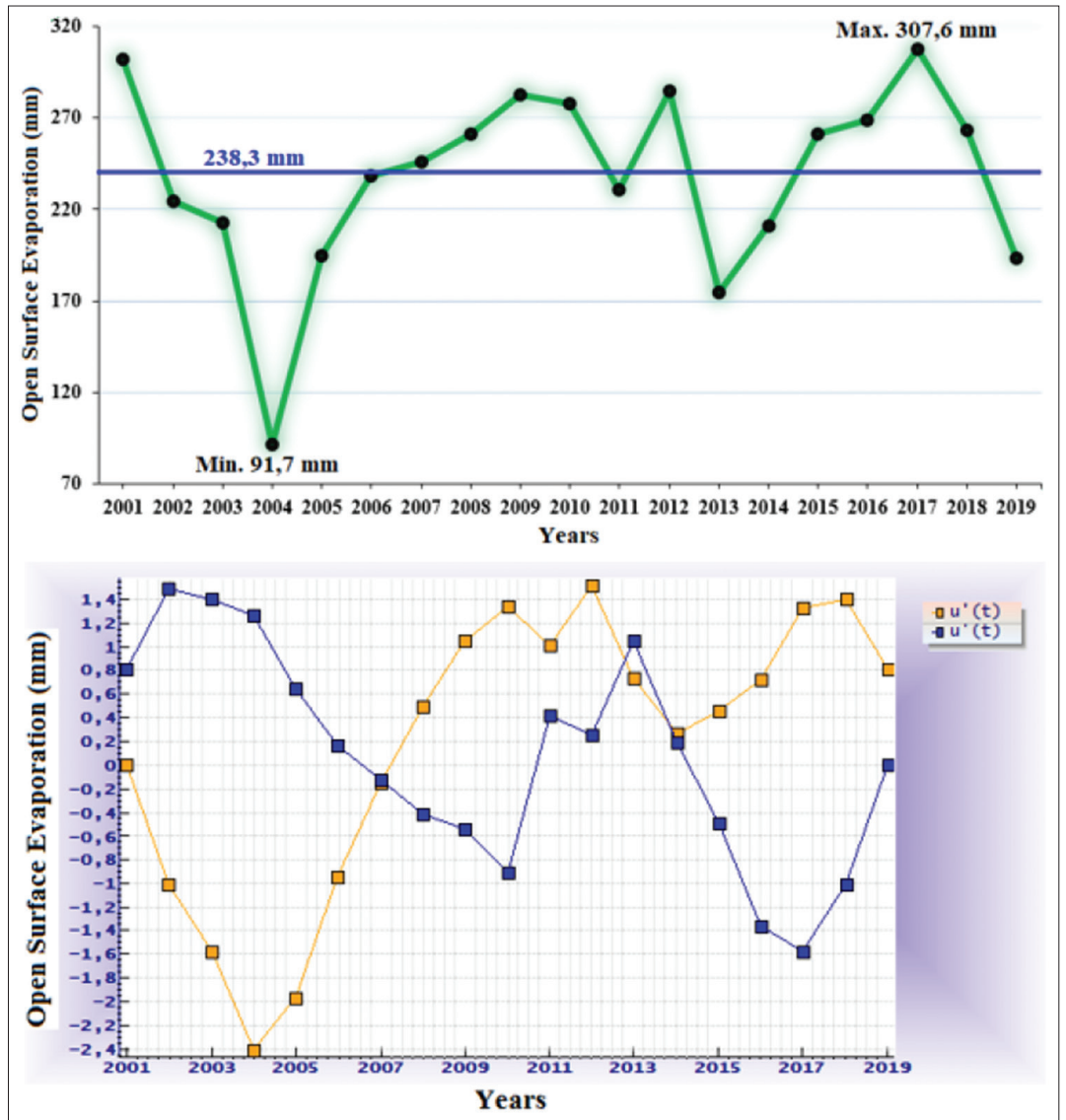

Figure 7: The average of the total open surface evaporation $(\mathrm{mm})$ in autumn months $(\mathrm{mm})$ over long periods

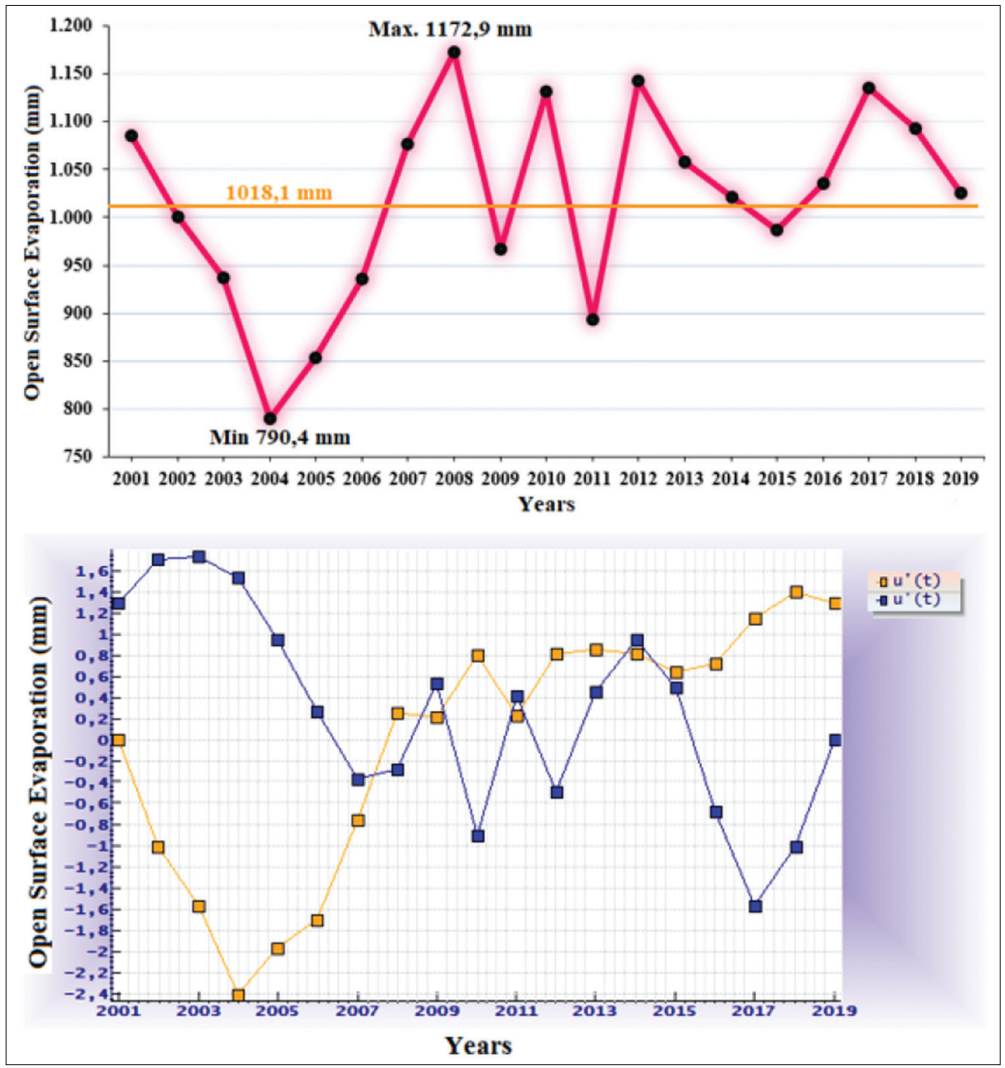

Figure 8: The average of the total open surface evaporation $(\mathrm{mm})$ in all months $(\mathrm{mm})$ over long periods 


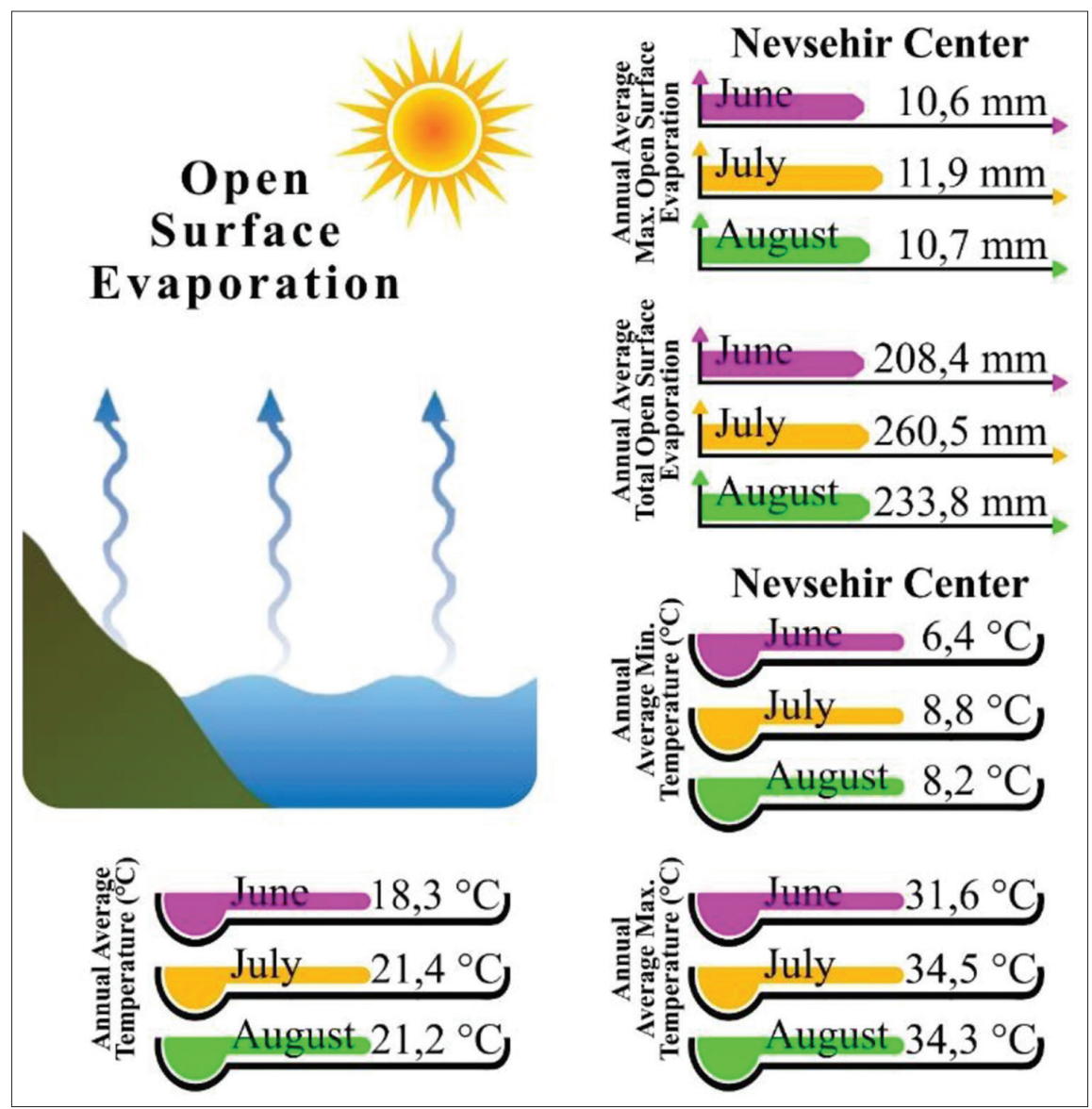

Figure 9: Summary distribution of all results for open surface evaporation over long period in Nevsehir province of Turkey

evaporation values observed as the average of all seasons for many years is presented in Figure 8.

Looking at the total open surface evaporation average values for many years, the lowest was $853,8 \mathrm{~mm}$ in 2005 , the highest was $1172,9 \mathrm{~mm}$ in 2008 and the total open surface evaporation average was $1017,3 \mathrm{~mm}$ for long years. Trend analysis results in total open surface evaporation changes for many years are given in Table 2.

According to the trend analysis results regarding maximum open surface evaporation for many years, it is concluded that there is no trend on the basis of spring, autumn, summer and general totals and that the open surface evaporation values progress in the average course according to Rho Tests of Mann-Kendall and Sperman.

Considering the average open surface evaporation value for 19 years, the average open surface evaporation value of 19 years was $10.6 \mathrm{~mm}$, while this value was recorded as $11,9 \mathrm{~mm}$ for July and 10,7 mm for August. Considering the average value of open surface evaporation in June for many years, the average open surface evaporation value of 19 years was $208.4 \mathrm{~mm}$, while this value was recorded as $260,5 \mathrm{~mm}$ in July and $233,5 \mathrm{~mm}$ in August. The average minimum temperature of 49 years in Nevşehir province, the temperature in June was $6,4^{\circ} \mathrm{C}$, while this value was found as $8,8^{\circ} \mathrm{C}$ in July and $8,2^{\circ} \mathrm{C}$ in August. The average maximum temperature values, while the temperature in June was $31,6{ }^{\circ} \mathrm{C}$, this value was observed as $34,5^{\circ} \mathrm{C}$ in July and $34,3^{\circ} \mathrm{C}$ in August. The average temperature values of the central district of Nevşehir were $18,3^{\circ} \mathrm{C}$ in June, while this value was $21,4^{\circ} \mathrm{C}$ in July and $21,2^{\circ} \mathrm{C}$ in August. Summary distribution of all results is given in Figure 9.

\section{CONCLUSION AND SUGGESTIONS}

Based on long years (2001-2019), total and maximum open surface evaporation values were subjected to 19 year and 228 months evaluation on a monthly basis. In this study carried out within the scope of evaluating open surface evaporation changes based on global climate change for many years in the district of Nevşehir, it was concluded that there was an increasing tendency in open surface evaporation. The fact that open surface evaporation tends to increase in parallel with the increase of precipitation and temperatures, which are of vital importance for living things, will lead to gradual depletion of water resources, endangerment of living life, and negative yield losses in agricultural production. In particular, measures to minimize the impact of greenhouse gases should be taken all over the world and will trigger this Increasing the necessary studies and measures to minimize the emissions of carbon emissions will play an important role in reducing the effects of global warming. 


\section{REFERENCE}

1. Ahrens DC. Meteorology Toda, An Introduction to Weather, Climate an The Environment, Fift Edition, West Publishing Company, USA, 1994.

2. Anonymous The Scientific Basic Contribution of Working Group I to The Third Assesment Report of The Intergovernmental Panel on Climate Change (IPCC), Cambridge University Press, Cambidge. 2001.

3. Türkes M. Vulnerability of Turkey to Desertification with Respect to Precipitation Andridity Conditıon, Ankara, 1999.
4. Anonymous. Nevşehir Merkez İlçesi Meteoroloji İstasyonu 2001-2019 yılları arası açık yüzey buharlaşması ve sıcaklık değerleri, Meteoroloji Genel Müdürlüğü, Ankara. 2019. (in turkish).

5. Mann HB, Non-parametric Tests Against Trend. Econometrica, 1945: (13)245-259.

6. Kendall M G. Rank Correlation Methods. Charles Griffin, London, 1975:135.

7. Gümüş V, Yenigün K. Fırat Havzası Akımlarının Trend Analizi İle Değerlendirilmesi, Harran Üniversitesi Fen Bilimleri Enstitüsü İnşaat Mühendisliği Anabilim Dalı, Yüksek Lisans Tezi, 2006, Şanlıurfa (in turkish). 